\title{
MENINGKATKAN ECOLITERACY SISWA SD MELALUI METODE FIELD- TRIP KEGIATAN EKONOMI PADA MATA PELAJARAN ILMU PENGETAHUAN SOSIAL
}

\section{Rana Gustian Nugraha}

\section{PGSD UPI Kampus Sumedang}

Jl. Mayor Abdurachman No. 211 Sumedang

Email:smd_stkip@yahoo.com

\begin{tabular}{|c|c|}
\hline ABSTRACT & ABSTRAK \\
\hline $\begin{array}{l}\text { The purpose of this research is to improve } \\
\text { ecoliteracy students through field-trip method of } \\
\text { the impact of economic activity in the form of } \\
\text { waste tahu. This study uses observations in the } \\
\text { form of method field-trip to the factory tahu and } \\
\text { the school environment. The method used in this } \\
\text { research is Classroom Action Research (clasroom } \\
\text { action research) in the fourth grade students of } \\
\text { SDN Lembur Situ, North Sumedang. Ecoliteracy } \\
\text { indicator of this research is to use an indicator of } \\
\text { Thomas Lickona (2012) in which there are } \\
\text { knowledge aspect, awareness and application. } \\
\text { The research instrument used was direct } \\
\text { observation of a student observation sheets, } \\
\text { questionnaires, student worksheets, test tool } \\
\text { evaluation and field record sheets were used to } \\
\text { obtain data through records in a form and } \\
\text { format that checklist done by the author and our } \\
\text { partners as an observer. Implementation of } \\
\text { classroom action research was conducted three } \\
\text { cycles. Results from this study is the increased } \\
\text { understanding, awareness and application of } \\
\text { students to ecoliteracy. } \\
\text { Keywords: ecoliteracy, field-trip, kegiatan } \\
\text { ekonomi, IPS, SD. }\end{array}$ & $\begin{array}{l}\text { Tujuan penelitian ini adalah untuk dapat } \\
\text { meningkatkan ecoliteracy siswa melalui metode } \\
\text { field-trip dampak kegiatan ekonomi yaitu berupa } \\
\text { limbah tahu. Penelitian ini menggunakan } \\
\text { pengamatan dalam bentuk metode filed-trip ke } \\
\text { pabrik tahu dan lingkungan sekolah. Metode } \\
\text { penelitian yang digunakan dalam penelitian ini } \\
\text { adalah Penelitian Tindakan Kelas (clasroom } \\
\text { action research) pada siswa kelas IV SDN Lembur } \\
\text { Situ Kecamatan Sumedang Utara. Indikator } \\
\text { ecoliteracy penelitian ini adalah menggunakan } \\
\text { indikator dari Thomas Lickona (20l2) yang } \\
\text { didalamnya terdapat aspek pengetahuan, } \\
\text { kesadaran dan aplikasi. Instrumen penelitian } \\
\text { yang digunakan adalah observasi secara } \\
\text { langsung berupa lembar observasi siswa, lembar } \\
\text { wawancara, lembar kerja siswa, alat tes evaluasi } \\
\text { dan lembar catatan lapangan yang digunakan } \\
\text { untuk memperoleh data melalui catatan dalam } \\
\text { bentuk format dan daftar isian yang dilakukan } \\
\text { oleh penulis dan mitra peneliti sebagai observer. } \\
\text { Pelaksanaan penelitian tindakan kelas ini } \\
\text { dilakukan tiga siklus. Hasil dari penelitian ini } \\
\text { adalah meningkatnya pemahaman, kesadaran } \\
\text { dan aplikasi siswa terhadap ecoliteracy. } \\
\text { Kata kunci: ecoliteracy, field-trip, kegiatan } \\
\text { ekonomi, IPS, SD. }\end{array}$ \\
\hline
\end{tabular}

How to Cite: Nugraha, R. (2015). MENINGKATKAN ECOLITERACY SISWA SD MELALUI METODE FIELD-TRIP KEGIATAN EKONOMI PADA MATA PELAJARAN ILMU PENGETAHUAN SOSIAL. Mimbar Sekolah Dasar, 2(1), $60-72$. doi:http://dx.doi.org/10.17509/mimbar-sd.v2i1.1322.

\section{Pendahuluan IImu Pengetahuan Sosial}

(IPS) merupakan mata pelajaran wajib bagi setiap satuan pendidikan, karena pada hakikatnya manusia itu hidup tidak bisa terlepas dari orang disekelilingnya. Melalui IPS manusia akan mendapatkan pengetahuan bagaimana cara berinteraksi yang baik dengan manusia lain ataupun dengan alam yang berada disekitarnya. IPS merupakan mata pelajaran yang diberikan pada jenjang pendidikan formal, mulai dari tingkat sekolah dasar sampai sekolah menengah. IPSI di sekolah dasar bertujuan 
mengenalkan siswa dengan kondisi yang nyata terhadap kehidupan di masyarakat dan lingkungan, memiliki nilai-nilai sosial, dan berinteraksi dengan baik terhadap orang lain dan alam sekitar. Menurut Depdiknas (2008, p. 45) tujuan IPS adalah sebagai berikut:

1. Mengenal konsep-konsep yang berkaitan dengan kehidupan mayarakat dan lingkungannya.

2. Memiliki kemampuan dasar untuk berpikir kritis logis dan kritis, rasa ingin tahu, inkuri, memecahkan masalah, dan keterampilan dalam kehidupan sosial.

3. Memiliki komitmen dan kesadaran terhadap nilai-nilai sosial dan kemanusiaan.

4. Memiliki kemampuan berkomunikasi, bekerjasama dan berkompetisi dalam masyarakat yang majemuk, di tingkat lokal, nasional, dan global.

Tujuan pembelajaran IPS tersebut dapat dicapai mellavi prosea belajar yang dilaksanakan di sekolah Melalui belajar seseorang akan tampak perbedaan dengan makhluk lainnya. Muhibbin (1995, p. 92) mengemukakan bahwa "Belajar dapat dipahami sebagai tahapan perubahan seluruh tingkah laku individu yang relatif menetap sebagai hasil pengalaman dan interaksi dengan lingkungan yang melibatkan proses kognitif".

Proses belajar itu tidak terlepas dari hubungan interaksi seseorang dengan lingkungan di sekitarnya. Lingkungan tersebut sangat mendukung seseorang dalam proses belajar. Pengetahuan seseorang akan masuk ke dalam memori otaknya bila adanya suatu pengalaman, artinya pengetahuan didapatkan tidak langsung secara utuh, melainkan pengetahuan itu masuk ke dalam memori otak secara sedikit demi sedikit.

Dalam hal ini sejalan dengan pendapat Baharudin dan Esa (2007, p. 116) yang mengatakan bahwa, "Teori konstruktivisme adalah membangun pengetahuan sedikit demi sedikit, yang kemudian hasilnya diperluas melalui konteks yang terbatas dan tidak sekonyong konyong".

Dalam pembelajaran IPS sangatlah penting didalamnya ditujukan untuk meningkatkan ecoliteracy. Ecoliteracy berasal dari kata literacy yang berarti melek dan eco yang berarti ekologi. Definisi dari ecoliteracy adalah: Kemampuan untuk memahami sistem alam yang membuat kehidupan di bumi. Untuk menjadi sarana ekoliterasi ini memahami prinsip-prinsip organisasi masyarakat dalam ekosistem dan menggunakan prinsip-prinsip untuk menciptakan komunitas manusia yang berkelanjutan (Wikipedia: http://en.wikipedia.org/wiki/Ecologic al_literacy).

Ecoliteracy bertujuan untuk meningkatkan kesadaran ekologis masyarakat. Sebagaimana yang dinyatakan oleh Rafsanjani (2008) "Ecoliteracy berupaya memperkenalkan dan memperbarui pemahaman masyarakat akan pentingnya kesadaran ekologis global, 
Rana Gustian Nugraha, Meningkatkan Ecoliteracy Siswa SD...

guna menciptakan keseimbangan antara kebutuhan masyarakat dan kesanggupan bumi untuk menopangnya".

Dalam proses pembelajaran seorang guru harus memperhatikan komponenkomponen pembelajaran. Komponen pembelajaran itu terdiri dari tujuan pembelajaran, guru, siswa, model, materi, media, sumber belajar dan evaluasi, dari kesemua komponen tersebut satu sama lain saling mendukung dalam mencapai keberhasilan pembelajaran. Sumber belajar merupakan salah satu komponen dalam pembelajaran, sehingga kesesuaian suatu sumber pembelajaran akan berpengaruh terhadap keberhasilan pembelajaran. Sumber belajar itu sangat banyak sekali ragamnya, salah satu diantaranya adalah lingkungan. Menurut Sugiarto (2014) tidak bisa dipungkiri bahwa lingkungan (alam-fisik dan sosial-budaya) memberikan outcome bagi perilaku manusia, termasuk anak. Lingkungan sebagai sumber belajar menurut Suhardjono (2004) merupakan "Kesatuan ruang dengan semua benda dan keadaan makhluk hidup, termasuk didalamnya manusia dan prilakunya serta makhluk hidup lainnya yang dapat memberikan kemudahan bagi siswa untuk memperoleh pengetahuan". Sumber belajar ini mengarahkan pada pembelajaran yang mendekatkan siswa dengan lingkungan yang berada disekitar siswa, maksudnya lingkungan tersebut dijadikan objek belajar siswa dalam memperoleh pengetahuannya.
Berdasarkan hasil observasi peneliti pada tanggal 15 Juni 2012 di kelas IV SDN Lembur Situ Kecamatan Sumedang Utara Kabupaten Sumedang, peneliti menemukan sebuah masalah dimana terdapat tempat kegiatan ekonomi di dekat SDN Lembur Situ yaitu pabrik tahu.

Permasalah yang terjadi adalah limbah dan polusi pabrik tersebut melewati aliran sungai warga setempat dan tempat tinggal siswa-siswa bermukim. Peneliti melakukan sebuah penelitian dengan siswa sebagai subjeknya untuk mengobservasi bahaya dari dampak pabrik tahu tersebut, dengan menganalisa bagaimana proses pembuatan tahunya, apakah air yang digunakan menggunakan air bersih?, apakah limbah air tahu sangat berbahaya bila dibuang ke sungai?, dan siswa dapat mengenal polusi apa saja yang dapat ditimbulkan dari pabrik tahu tersebut.

Field-Trip ke pabrik tahu dalam permasalahan ini dapat diterapkan untuk meningkatkan ecoliteracy siswa dalam hal limbah tahu. Pelaksanaan pembelajarannya guru menyampaikan materi secara langsung pada siswa, dan siswa ditugaskan mengamati apa yang sesungguhnya terjadi di sekitar pabrik tahu tersebut, dengan begitu siswa akan mendapatkan pengalaman belajar tentang pentingnya menjaga lingkungan.

Dengan memperhatikan asumsi tersebut, maka dalam penelitian ini penulis 
mengambil judul "Meningkatkan Ecoliteracy siswa SD Melalui Metode FieldTrip Kegiatan Ekonomi Pada Mata Pelajaran IImu Pengetahuan Sosial. (Penelitian Tindakan Kelas di Kelas IV SDN Lembur Situ Kabupaten Sumedang)".

Berdasarkan penelitian yang dilakukan, permasalahan yang muncul adalah kurangnya kesadaran lingkungan siswa tentang dampak kegiatan ekonomi di lingkungan sekitarnya. Oleh karena itu penulis merumuskan permasalahan tersebut sebagai berikut: "Bagaimana peningkatan ecoliteracy siswa setelah mengamati dampak kegiatan ekonomi dengan menggunakan metode field-trip pada mata pelajaran IPS di kelas IV SDN Lembur Situ Kecamatan Sumedang Utara Kabupaten Sumedang?".

Untuk memecahkan masalah yang telah dirumuskan di atas, maka peneliti harus bisa menerapkan metode pembelajaran yang dapat mengatasi permasalahan tersebut, maka peneliti menggunakan metode field-trip ke pabrik tahu dan lingkungan sekolah untuk meningkatkan ecoliteracy.

Metode field-trip ini, akan menimbulkan dampak positif pada siswa dalam meningkatan ecoliteracy terhadap lingkungan. Siswa sendiri yang melakukan pengamatan terhadap lingkungan yang nyata, maka melalui metode field-trip ini siswa langsung berinteraksi dengan apa yang akan diamatinya tersebut.
Berdasarkan pemecahan masalah di atas, maka peneliti menargetkan selama proses penggunaan pengamatan langsung adalah sebagai berikut:

a. Pemahaman

b. Kesadaran

c. Aplikasi

Kemudian target dari hasil pembelajaran ini secara umum siswa dapat memahami bahaya limbah tahu, dan secara khusus siswa dapat memiliki sikap ecoliteracy yang baik.

\section{Ecoliteracy}

Ecoliteracy atau dalam bahasa Indonesianya ekoliterasi berasal dari kata eco dan literacy. Eco adalah ekologi yang berarti ilmu yang mempelajari tentang hubungan timbal balik antara manusia dan lingkungan. Sedangkan litercy yang berarti melek, terampil, paham atau sadar.

Ecologi menurut Capra (2002, p. 53) adalah "Studi mengenai hubunganhubungan yang memperhubungkan segenap anggota Rumah Tangga Bumi". Literacy diartikan oleh kita sebagai kesadaran. Menurut Buletin Para Navigator dalam Neolaka (2008, p. 19) menyatakan bahwa:

Kesadaran adalah modal utama bagi setiap orang yang ingin maju. Secara garis besar sadar itu dapat diukur dari berbagai aspek, antara lain : kemampuan membuka mata dan menafsirkan apa yang dilihat, kemampuan aktivitas, dan kemampuan berbicara.

Monowito dalam Neolaka (2008, p. 19) menyatakan bahwa "Kesadaran manusia 
Rana Gustian Nugraha, Meningkatkan Ecoliteracy Siswa SD...

dalam sadar itu dinamakan kesadaran, atau dapat dibalik bahwa kesadaran ialah keadaan manusia dalam sadar/ siuman"

Menurut Capra (2002, p. 51), ada dua tipe kesadaran yaitu,

Tipe pertama, yang dikenal sebagai kesaran primer (primary consciousness), muncul bila prosesproses kognitif disertai pengalaman perceptual, indrawi, dan emosional dasar. Tipe kedua, yang terkadang disebut kesadaran tingkat tinggi (higher order consciousness) melibatkan swakesadaran (self awareness) yaitu suatu konsep diri yang dimiliki suatu subjek yang berpikir dan merenung.

Sedangakan Ekologi menurut Soemarwoto (1991, p. 19)

Ekologi dapat dikatakan ekonomi alam, yang melakukan transaksi dalam bentuk materi, energi dan informasi. Ekologi dan ekonomi mempunyai banyak persamaan, hanya saja dalam ekologi mata vang yang dipakai dalam transaksi bukanlah uang, melainkan materi, anergi, dan informasi. Arus materi, energi dan informasi dalam suatu komunitas atau antara beberapa komunitas mendapat perhatian utama dalam ekologi, seperti halnya arus vang dalam ekonomi.

Ekologi mencoba memahami hubungan timbal balik, interaksi antara tumbuhtumbuhan, binatang, manusia dengan alam lingkungannya, agar dapat menjawab pertanyaan dimana mereka hidup, bagaimana mereka hidup dan mengapa mereka hidup disana.

Bila kita gabungkan maka ekoliterasi ini akan menjadi sebuah makna yaitu kesadaran lingkungan. Kesadaran lingkungan menurut M.T. Zen dalam Neolaka (2008, p. 20),

Usaha melibatkan setiap warga negara dalam menumbuhkan dan membina kesadaran untuk melestarikan lingkungan, berdasarkan tata nilai, yaitu tata nilai dari pada lingkungan itu sendiri dengan filsafat hidup secara damai dengan alam lingkungannya.

Asas ini harus mulai ditumbuhkan melalui pendidikan sekolah dan luar sekolah, dari taman kanak-kanak hingga perguruan tinggi agar lambat laun tumbuh rasa cinta kepada alam lingkungan, disertai tanggung jawab sepenuhnya setiap manusia untuk memelihara kelestarian lingkungan.

Emil Salim dalam Neolaka (2008: 19) menyatakan kesadaran lingkungan sebagai berikut:

Kesadaran lingkungan adalah upaya untuk menumbuhkan kesadaran agar tidak hanya tahu tentang sampah, pencemaran, penghijauan dan perlindungan satwa langka, tetapi lebih daripada itu semua, membangkitkan kesadaran lingkungan manusia Indonesia khususnya pemuda masa kini, agar mencintai tanah dan air untuk membangun tanah air Indonesia yang adil, makmur serta utuh liestari.

Selanjutnya dikatakan bahwa sadar lingkungan ini mendorong pribadi manusia untuk hidup serasi dengan alam dan dengan begitu menumbuhkan rasa religi dan gandrung akan kasih Allah SWT yang sesungguhnya tertulis melalui isi bumi ini. 
Beberapa pakar multidisiplin dari berbagai negara berkumpul dalam Intergovernmental Panel on Climate Change of the United Nations pada tahun 1988. Mereka mencoba menganalisis kemungkinan penyebab rangkaian bencana dalam beberapa tahun terakhir. Sebuah hipotesis kemudian dimunculkan bahwa pemanasan global akibat emisi gas rumah kaca, dapat memicu perubahan iklim global, menghadirkan gelombang panas, memicu kenaikan permukaan laut, termasuk kekeringan dan banjir yang datang silih berganti.

Perubahan iklim global, bukan semata berdampak pada keseimbangan alam, tetapi juga memiliki trickle down effect yang berbahaya bagi kehidupan manusia. Entah itu akibat polutan atau penyebaran serangga-serangga pembawa penyakit yang berkembang biak seiring makin panasnya cuaca.

Ancaman luar biasa dari pemanasan global juga demi keberlangsungan bumi di masa depan, membuat upaya-upaya anti tesis bagi pemanasan global menjadi arus utama perdebatan masyarakat dunia. Kita pun mengenal frasa think globally, act locally, yang menggambarkan kontribusi perbaikan alam di tingkat lokal terhadap keseimbangan global.

Itu merupakan dampak besar yang kemungkinan terjadi dimasa depan, dalam hal yang terkecil dampak perusakan lingkungan sekitar makin marak kita jumpai, seperti halnya limbah-limbah yang menggenangi sungai, tanah, udara yang terkena polusi dari pabrik-pabrik.

Ekoliterasi berupaya memperkenalkan dan memperbarui pemahaman masyarakat akan pentingnya kesadaran ekologis global, guna menciptakan keseimbangan antara kebutuhan masyarakat dan kesanggupan bumi untuk menopangnya. Rafsanjani (2008), menyatakan:

Dengan tingkat 'melek ekologis' yang baik, desain-desain dalam berbagai bidang kehidupan juga akan berbasis ekologi. Dengan demikian, setiap bidang kehidupan

(eco-economy, eco-farming, ecomanagement, hingga eco-city) dapat dirancang dengan corak ekologis yang kental. Hal ini membuat ecoliteracy menjadi instrumen yang sangat penting. Terutama, karena kebijakan-kebijakan yang mengintegrasikan pembangunan dan keseimbangan ekologis, hanya akan muncul dari stakeholder yang mengetahui dengan baik nilai-nilai ekologi tersebut. Ekoliterasi menjadi amat penting di negeri di mana para pejabat (penguasa) dan pengusaha berkolusi melahirkan kebijakan yang tidak prolingkungan.

Selain menjadikan arus utama perdebatan masyarakat, komunitas-komunitas hijau juga mengampanyekan integrasi antara ideologi kontra pemanasan global dan konsepsi pembangunan berkelanjutan (sustainable development).

Pembangunan berkelanjutan ini diawali sekelompok masyarakat dengan pemahaman kognitif yang memadai 
Rana Gustian Nugraha, Meningkatkan Ecoliteracy Siswa SD...

tentang hakikat dan prinsip-prinsip ekologi.

Proses meningkatkan pemahaman inilah yang dinamakan ecological literacy atau ecoliteracy.

\section{Metode Field-Trip}

Metode field-Trip disebut jug metode karua wisata. Menurut Roestiyah (2008, p. 85)

Karya wisata bukan sekedar rekreasi, tetapi untuk belajar atau memperdalam pelajarannya dengan melihat kenyataannya. Karena itu dikatakan teknik karya wisata ialah cara mengajar yang dilaksakan dengan mengajak siswa ke suatu tempat atau obyek tertentu di luar sekolah untuk mempelajari atau menyelidiki sesuatu seperti meninjau pabrik sepatu, suatu bengkel mobil, toko serba ada, peternakan, perkebunan, lapangan bermain dan sebagainya.

Sedangkan Surakhman (1980, p. 115) mengatakan bahwa, "Metode karyawisata atau field-trip adalah metode belajar dan mengajar di mana siswa dengan bimbingan guru diajak untuk mengunjungi tempat tertentu dengan maksud untuk belajar". Berbeda halnya dengan tamasya di mana seseorang pergi untuk mencari hiburan semata, field trip sebagai metode belajar mengajar lebih terikat oleh tujuan dan tugas belajar mengunjungi tempat tertentu dengan maksud untuk belajar".

Dari beberapa pendapat di atas dapat disimpulkan bahwa metode field-trip merupakan metode penyampaian materi pelajaran dengan cara membawa langsung siswa ke obyek di luar kelas atau di lingkungan yang berdekatan dengan

sekolah agar siswa dapat mengamati atau mengalami secara langsung.

Setiap metode yang digunakan sudah pasti mempunyai keunggulan dan kelemahan. Suhardjono (2004, p. 85) mengungkapkan bahwa metode field-trip memiliki keunggulan seperti:

a. Memberikan informasi teknis, kepada peserta secara langsung,

b. Memberikan kesempatan untuk melihat kegiatan dan praktik dalam kenyataan atau pelaksanaan yang sebenarnya,

c. Memberikan kesempatan untuk lebih menghayati apa yang dipelajari sehingga lebih berhasil,

d. Memberi kesempatan kepada peserta didik untuk melihat di mana peserta ditunjukan kepada perkembangan tekhnologi mutakhir.

Setiap ada kelebihan sudah tentu mempunyai kekurangan adapun kekurangan dari metode field trip menurut Suhardjono (2004, p. 85) adalah:

a. Memakan waktu bila lokasi yang dikunjungi jauh dari sekolah,

b. Kadang-kadang sulit untuk mendapat izin dari pimpinan/Kepala sekolah atau kantor yang akan dikunjungi,

c. Biaya transportasi dan akomodasi mahal. 
Menurut pendapat para ahli di atas tentang kelemahan-kelemahan metode field trip, disini peneliti sudah memikirkannya sebelum mengangkat judul dengan menggunakan metode field-trip ini, menurut Suhardjono (2004, p. 85)

Metode field-trip itu memerlukan biaya yang lebih mahal dan memakan waktu lebih bila lokasinya jauh dari sekolah, maka dari itu untuk menghindari hal tersebut peneliti mengambil lokasi yang tidak jauh dari sekolah, sehingga dalam biaya akan jauh lebih irit karena tidak memerlukan transportasi, akan lebih menghemat waktu dan mempermudah perizinan dari kepala sekolah.

\section{METODE}

Penelitian ini menggunakan metode Penelitian Tindakan Kelas (PTK). Menurut Wiriaatmadja (2005, p. 13). "Penelitian tindakan kelas adalah bagaimana sekelompok guru dapat mengorganisasikan kondisi praktek pembelajaran mereka, dan belajar dari pengalaman mereka sendiri". Penelitian ini mampu menawarkan pendekatan dan prosedur yang mempunyai dampak langsung untuk perbaikan dan peningkatan profesionalisme guru dalam mengelola pembelajaran di kelas.

Tujuan utama penelitian tindakan kelas ini adalah untuk memperbaiki praktek pembelajaran di kelas. Namun dalam penelitian tindakan kelas ini pembelajaran akan dilakukan berupa pengamatan di luar kelas yaitu di pabrik tahu yang bertujuan mengamati limbah dan dampak kegiatan pabrik tahu serta mengamati lingkungan sekolah. Penelitian tindakan kelas ini merupakan suatu bentuk penelitian yang dilakukan ketika proses belajar mengajar berlangsung yang bersifat reflektif kolaboratif dengan melalakukan tindakan-tindakan yang tepat dengan subjek yang diteliti adalah siswa.

Penelitian tindakan kelas ini berfokus pada upaya untuk meningkatkan ekoliterasi dengan menggunakan metode pengamatan langsung terhadap kegiatan ekonomi masyarakat setempat. Dalam kajian ini, penelitian tindakan dilakukan untuk meningkatkan pemahaman, kesadaran dan aplikasinya.

\section{Desain Penelitian}

Adapun model penelitian yang digunakan penulis adalah model siklus Kemmis dan Mc Taggart (1998) yang diadaptasi dari Wiriaatmadja (2005, p. 66), terdiri dari empat komponen yaitu, rencana tindakan, pelaksanaan tindakan, observasi, dan refleksi. Desain penelitian menurut Kemmis dan Mc. Taggart, yaitu model siklus yang dilakukan secara berulang-ulang, semakin lama diharapkan semakin meningkat perubahannya atau pencapaian hasilnya.

Sistem spiral refleksi diri yang dimulai dengan rencana, tindakan, pengamatan, refleksi, perencanaan kembali merupakan dasar untuk suatu ancang-ancang pemecahan masalah. Sebagaimana tampak pada gambar di bawah ini. 


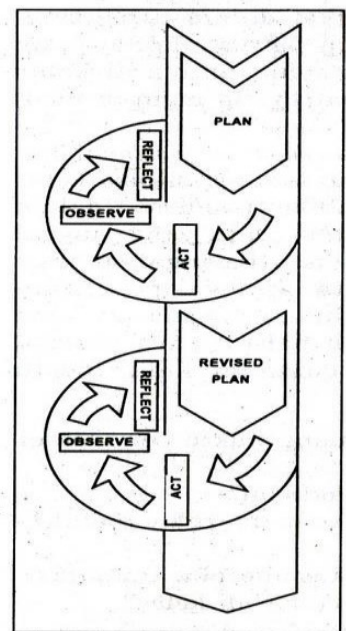

Gambar 1. Model Spiral Kemmis dan Mc Taggart (1998) (Diadaptasi Dari Wiriaatmadja, 2005: 66).

\section{HASIL DAN PEMBAHASAN}

Siklus 1 Pengamatan ke Pabrik Tahu A

Perhatikan beberapa kegiatan siswa dalam gambar di bawah ini.

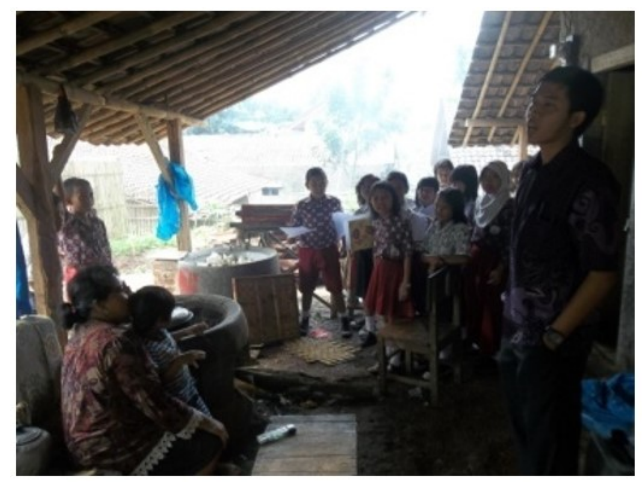

Gambar 1. Suasana Siswa Sedang Melakukan Pengamatan Langsung Ke Pabrik Tahu A

Siklus 2 Pengamatan ke Pabrik Tahu B

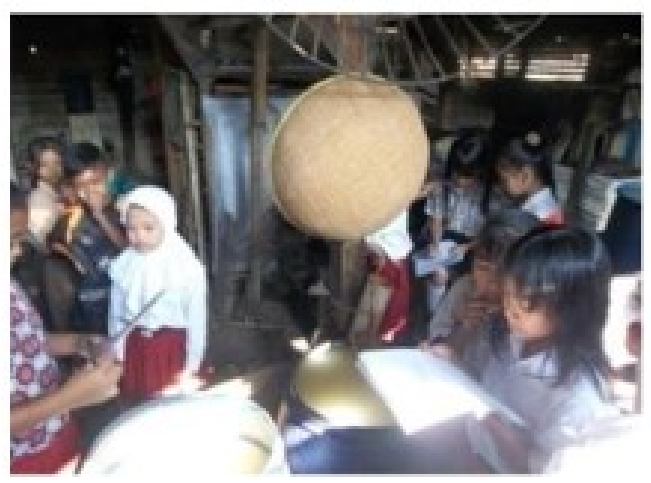

Gambar 2. Suasana Siswa Sedang Melakukan Pengamatan Langsung Ke Pabrik Tahu B 


\section{Siklus 3 Pengamatan di Lingkungan Sekolah}

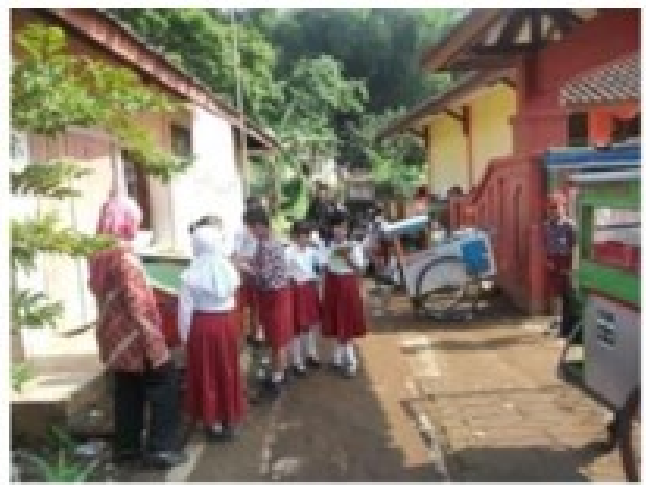

\section{Gambar 3. Siswa Sedang Melakukan Pengamatan di Lingkungan Sekitar Sekolah}

Setelah dilakukan pembelajaran selama tiga siklus ini terjadi perubahan sikap pada masing-masing siswa di antaranya:

1. Siswa sadar bahwa semua kegiatan manusia sehari-hari itu telah berdampak buruk pada lingkungan.

2. Siswa sadar akan pentingnya penjagaan lingkungan sekolah, rumah dan masyarakat.

3. Siswa sadar pemahaman tentang kebersihan kurang baik jika aplikasinya tidak dilakukan dengan baik.

4. Siswa semakin sadar bahwa setiap lingkungan bersih akan menciptakan suasana yang nyaman untuk tinggal.

5. Siswa sadar menjaga kebersihan itu tidaklah sulit.

Dengan munculnya kesadaran-kesadaran tersebut menandakan bahwa siswa telah mencapai ekoliterasi atau kesadaran lingkungan. Kesadaran lingkungan menurut M.T. Zen dalam Neolaka (2008, p. 20),
Usaha melibatkan setiap warga negara dalam menumbuhkan dan membina kesadaran untuk melestarikan lingkungan, berdasarkan tata nilai, yaitu tata nilai dari pada lingkungan itu sendiri dengan filsafat hidup secara damai dengan alam lingkungannya.

Upaya perbaikan sikap dan nilai yang menyangkut aktivitas guru maupun siswa dengan pembelajaran yang dilakukan di luar kelas kegiatan field-trip atau karya wisata terbukti sangat membantu pencapaian tujuan. Menurut Roestiyah (2008, p. 85), karya wisata bukan sekedar rekreasi, tetapi untuk belajar atau memperdalam pelajarannya dengan melihat kenyataannya. Hal ini terbukti pada data empiris di lapangan, hasil pemahaman, kesadaran dan aplikasinya melalui metode pembelajaran field-trip ke tempat kegiatan ekonomi masyarakat yang dilakukan dari siklus I sampai siklus III telah meningkatan hasil tiap siklus dengan bertahap. Ketika pembelajaran sampai pada siklus III, persentase ketuntasan belajar dalam hal pemahaman meningkat 
yang semula pada siklus | 30\%, siklus || $60 \%$ dan pada siklus ke III menjadi 85\%. Untuk lebih jelasnya dapat dilihat pada grafik berikut

ini:

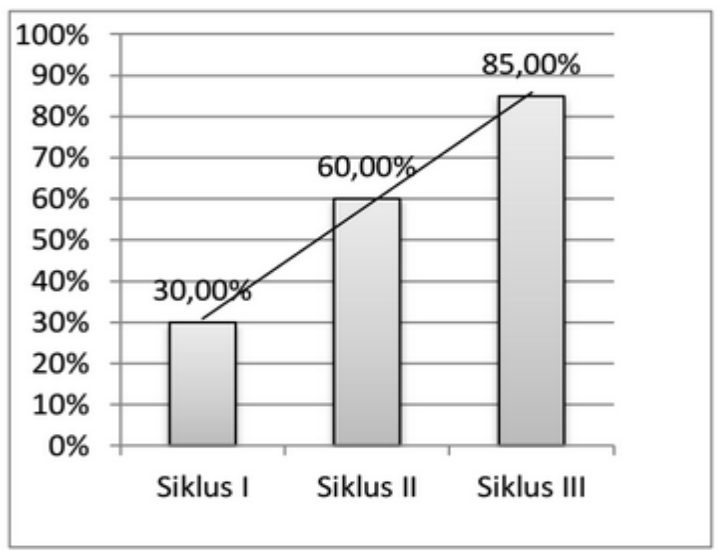

\section{Grafik 1. Peningkatan Hasil Pemahaman Dari Siklus I, Siklus II dan Siklus III}

Sedangkan hasil kesadaran dan aplikasi siswa juga tidak lepas dari peningkatan karena didukung dengan pemahaman siswa yang setiap siklus meningkat maka berpengaruh dalam kesadaran dan aplikasi siswa selama pembelajaran. Ketika pembelajaran sampai pada siklus III, persentase hasil kesadaran dan aplikasi siswa meningkat yang semula pada siklus I $37,50 \%$, siklus II $52,50 \%$ dan pada siklus ke III menjadi 81,60\%. Untuk lebih jelasnya dapat dilihat pada grafik berikut ini.

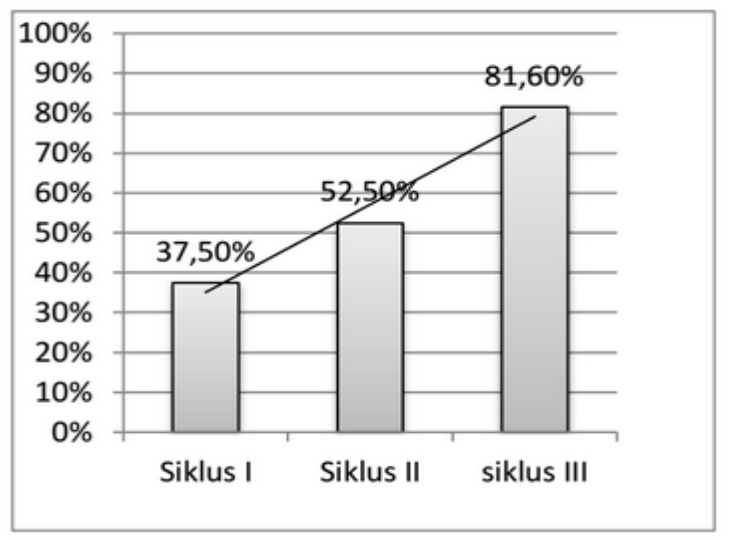

Grafik 2. Peningkatan Hasil Kesadaran dan Aplikasi Dari Siklus I, Siklus II dan Siklus III

Berikut ini data perkembangan ecoliteracy siswa melalui pengamatan langsung ke pabrik tahu yang mengamati tentang limbah tahu untuk meningkatkan kesadaran lingkungan di kelas IV SDN Lembur Situ Kabupaten Sumedang pada setiap siklusnya.

Tabel 1. Rekapitulasi Data Hasil Pemahaman, Kesadaran dan Aplikasi Siswa Kelas IV SDN Lembur Situ

\begin{tabular}{|l|c|c|c|c|}
\hline \multirow{2}{*}{\multicolumn{1}{|c|}{ Aspek Yang Diamati }} & \multicolumn{4}{c|}{ KETERANGAN } \\
\cline { 2 - 5 } & Data Siklus I & $\begin{array}{c}\text { Data Siklus } \\
\text { II }\end{array}$ & Data Siklus III & Ket \\
\hline Pemahaman & $30 \%(\mathrm{~T})$ & $55 \%(\mathrm{~T})$ & $85 \%$ (T) & T = Tuntas \\
\hline Kesadaran dan Aplikasi Siswa & $37,50 \%$ & 52,50 & 81,60 & \\
\hline
\end{tabular}

Dari tabel di atas diketahui terjadi perubahan pencapaian target pada setiap siklusnya, hal ini membuktikan bahwa dengan melakukan field-trip ke pabrik tahu dan pengamatan di lingkungan sekolah pada kelas IV SDN
Lembur Situ Kabupaten Sumedang berhasil dilakukan dengan hasilnya adalah ecoliteracy siswa meningkat. Dengan demikian terlihat jelas bahwa pembelajaran dengan field-trip telah meningkatkan hasil belajar siswa hal ini 
dikarenakan pembelajaran file trip memiliki keunggulan sebagaimana yang dinyatakan oleh Suhardjono (2004, p. 85) bahwa:

a. Memberikan informasi teknis, kepada peserta secara langsung,

b. Memberikan kesempatan untuk melihat kegiatan dan praktik dalam kenyataan atau pelaksanaan yang sebenarnya,

c. Memberikan kesempatan untuk lebih menghayati apa yang dipelajari sehingga lebih berhasil,

d. Memberi kesempatan kepada peserta didik untuk melihat di mana peserta ditunjukan kepada perkembangan tekhnologi mutakhir.

\section{SIMPULAN}

Berdasarkan hasil pemaparan data dan pembahasan mengenai penerapan metode field-trip kegiatan ekonomi masyarakat setempat pada pelajaran ilmu pengetahuan sosial untuk meningkatkan ecoliteracy siswa di kelas IV SDN Lembur Situ Kabupaten Sumedang, maka dapat ditarik kesimpulan sebagai berikut. Pada proses penelitian tindakan kelas ini, terdiri dari tahapan perencanaan yang dilakukan oleh guru, tahap pelaksanaan yang di dalamnya terdapat fokus penelitian adalah aktivitas siswa dalam meningkatkan pemahaman, kesadaran dan aplikasi siswa terhadap lingkungan sekitar. Tahap evaluasi yang difokuskan kepada pelaksanaan evaluasi berdasarkan pencapaian indikator pembelajaran.

Pada tahap pelaksanaan, siswa melakukan field-trip ke pabrik tahu A pada siklus I, pabrik tahu B pada siklus II dan pengamatan di lingkungan sekolah pada siklus III. Prosedur-prosedur yang sudah ditetapkan dan dengan cara berkelompok siswa melakukan pengamatan langsung dengan berbekal LKS kelompok, kemudian siswa diberikan sebuah tes hasil belajar individu untuk diketahui sejauh mana pemahaman masing-masing siswa. Dari hasil tes diperoleh data ketuntasan pada siklus | 30\%, siklus || 60\%, siklus III $85 \%$. Sedangkan aspek kesadaran dan aplikasi siswa dapat dilihat dan ternilai melalui observasi peneliti yang dibantu oleh empat guru. Persentase pencapaian kesadaran dan aplikasi siswa yang disatukan menjadi aktivitas siswa peneliti mendapatkan data hasil siklus | 37,50\%, siklus || 52,50\%, siklus ||I $81,60 \%$.

Berdasarkan deskripsi di atas data yang berasal dari hasil pengolahan dan analisis data sebagai hasil penelitian tindakan kelas, telah membuktikan bahwa hipotesis yang diajukan diterima.

\section{REFERENSI}

Depdiknas. (2008). Kurikulum Tingkat Satuan Pendidikan. Jakarta: Dikmenum Depdiknas.

Baharudin, H. dan Esa, W. N. (2007). Teori Belajar \& Pembelajaran. Jogjakarta: ArRuzz Media Group.

Capra, F. (2002). Jaring-Jaring Kehidupan. Yogyakarta: Fajar Pustaka Baru.

Capra, F. (2002). The Hidden Connections. Bandung: Jala Sutra.

Muhibbin, S. (1995). Psikologi Pendidikan Suatu Pendekatan Baru. Bandung: PT. Remaja Rosdakarya. 
Rana Gustian Nugraha, Meningkatkan Ecoliteracy Siswa SD...

Neolka, A. (2008). Kesadaran Lingkungan. Jakarta: Rineka Cipta.

Rafsanjani, A. (2008). Ekoliterasi. [online]. Available at Heilraff.Blogspot.com/2008/05/ekolitera si.html.

Roestyah. (2008). Strategi Belajar Mengajar. Jakarta: Rineka Cipta.

Soemarwoto, O. (1991). Ekologi Lingkungan Hidup dan Pembangunan. Jakarta: Djambatan.

Sugiarto, E. (2014). EKSPRESI VISUAL ANAK: REPRESENTASI INTERAKSI ANAK DENGAN LINGKUNGAN DALAM KONTEKS EKOLOGI BUDAYA. Mimbar Sekolah Dasar, 1(1), 1-6.

Suhardjono. (2004). Kekurangan Metode Field-Trip. [Online]. Available at: $\mathrm{http} / /$ mariaulfah 15.Multiply.com/journe $\mathrm{y} /$ item/3/metodepembelajaran.

Suhardjono. (2012). Penelitian Tindakan Kelas dan Tindakan Sekolah. Malang: Cakrawala Indonesia.

Surakhman, W. (1980). Pengantar Penelitian Ilmiah. Bandung: Tarsito.

Wiriaatmadja, R. (2005). Metode Penelitian Tindakan Kelas. Bandung: Remaja Rosdakarya. 